\title{
Spiroplasma leucomae sp. nov., isolated in Poland from white satin moth (Leucoma salicis L.) larvae
}

Correspondence

Gail E. Gasparich

ggasparich@towson.edu

\author{
Marietta A. Oduori, ${ }^{1}$ Jerzy J. Lipa ${ }^{2}$ and Gail E. Gasparich ${ }^{1}$ \\ ${ }^{1}$ Department of Biological Sciences, Towson University, Towson, MD 21252, USA \\ ${ }^{2}$ Department of Biocontrol and Quarantine, Institute of Plant Protection, Poznan, Poland
}

Spiroplasma sp. strain SMA ${ }^{\top}$, isolated in Poland from white satin moth larvae, Leucoma salicis $\mathrm{L}$. (Lepidoptera: Lymantriidae), was serologically distinct from other Spiroplasma species, groups or subgroups. Dark-field microscopy of the cells revealed the classical helical shape and subsequent transmission electron microscopy revealed cells surrounded by only a single cell membrane (lacking a cell wall). Growth of strain $\mathrm{SMA}^{\top}$ occurred in M1D medium at $30^{\circ} \mathrm{C}$. Strain $\mathrm{SMA}^{\top}$ catabolized both glucose and arginine, but did not hydrolyse urea. The $\mathrm{G}+\mathrm{C}$ content of the DNA was $24 \pm 1 \mathrm{~mol} \%$ as determined by melting temperature analysis. Serological analysis revealed a very weak cross-reactivity (positive reaction only up to a $1: 80$ dilution) with two Spiroplasma strains, 277F (Spiroplasma sp. group I-4) and LB-12 (Spiroplasma sp. group I-5). Strain SMA ${ }^{\top}\left(=\right.$ ATCC BAA-52 $1^{\top}=$ NBRC $\left.100392^{\top}\right)$ is designated the type strain of a novel species, Spiroplasma leucomae sp. nov. (class Mollicutes: order Entomoplasmatales: family Spiroplasmataceae).
Spiroplasma infection among white satin moth [Leucoma (=Stilpnotia) salicis L.] larvae was first discovered in 1986, which was the first record of spiroplasma infection in the insect order Lepidoptera (Lipa et al., 1988). Previous spiroplasma infections have been recorded in members of the insect orders Hymenoptera, Hemiptera, Coleoptera and Diptera and in ticks of the family Ixodidae (Hackett et al., 1990). Strain $\mathrm{SMA}^{\mathrm{T}}$ was isolated from a fifth instar larval satin moth collected in Poland (Lipa et al., 1988). Satin moth larvae were collected from poplar trees in 1986 and 1987, and data recorded a $43 \%$ natural infection from the 1986 collections and a range of 8·3-20\% infection in the 1987 collection (Lipa et al., 1988). Among laboratory-reared satin moth larvae, the infection level was higher, $55 \%$ among 41 examined larvae, indicating that horizontal transmission of the spiroplasmas was a means to spread the infection among members of a satin moth larvae population. As this is the first natural spiroplasma infection recorded in a lepidopteran, characterization of strain $\mathrm{SMA}^{\mathrm{T}}$ was performed.

The classification of spiroplasmas requires several morphological, biochemical and genetic tests as prescribed by the International Committee on Systematic Bacteriology Subcommittee on the Taxonomy of Mollicutes (1995). In

Published online ahead of print on 22 July 2005 as DOI 10.1099/ ijs.0.63685-0.

Abbreviations: DF test, deformation test; MI test, metabolism inhibition test.

The GenBank/EMBL/DDBJ accession number for the 16S rRNA gene sequence of strain $\mathrm{SMA}^{\top}$ is $\mathrm{DQ} 101278$. this paper, we report the results of taxonomic studies of strain $\mathrm{SMA}^{\mathrm{T}}$ that satisfy the requirements for species descriptions for the class Mollicutes (International Committee on Systematic Bacteriology Subcommittee on the Taxonomy of Mollicutes, 1995). Results support the designation of strain $\mathrm{SMA}^{\mathrm{T}}$ as the type strain of a novel species.

\section{Isolation and cultivation}

Techniques for isolating spiroplasmas from insect guts and haemocoel have been described previously (Hackett \& Clark, 1989; Rose et al., 1993). Strain SMA ${ }^{\mathrm{T}}$ was isolated and cultivated from the haemolymph of a larval satin moth ( $L$. salicis) collected in Poland (Lipa et al., 1988). Primary isolation of strain $\mathrm{SMA}^{\mathrm{T}}$ was performed in a culture of M1D medium (Whitcomb, 1983) and in a co-culture of M1D medium with insect tissue cells $(1: 1)$ (Konai et al., 1996b). For comparative purposes, strain $\mathrm{SMA}^{\mathrm{T}}$ was adapted to serum fraction medium (SFM; Smith et al., 1954), to which $10 \%$ glucose was added. Modifications were made to SFM by replacing Difco PPLO serum fraction with horse serum. Other media used for cultivation purposes included DCCM (Hackett et al., 1996), H-2 (Konai et al., 1996b) and a coculture of M1D/H-2 (1:1) (Konai et al., 1996b). Isolates of strain SMA ${ }^{\mathrm{T}}$ were grown at an optimal temperature of $30^{\circ} \mathrm{C}$ (Konai et al., 1996a) both aerobically and anaerobically in a BBL anaerobic GasPak system (Becton Dickinson). Growth of strain $\mathrm{SMA}^{\mathrm{T}}$ was determined by observing indicator changes in the medium (M1D) and by examining the cultures microscopically during a weekly observatory period. Initial inoculations of strain $\mathrm{SMA}^{\mathrm{T}}$ into M1D and 
M1D/TC media involved weekly passes due to the slow growth of the organism. Other media were used for comparative growth purposes: DCCM, H-2, SFM supplemented with $10 \%$ glucose and M1D/H-2. Slower growth rates were observed in all of these media. After a 1-month adaptation in M1D medium (containing $500 \mathrm{U}$ penicillin $\mathrm{ml}^{-1}$ ), strain $\mathrm{SMA}^{\mathrm{T}}$ grew rapidly, requiring daily passes. Strain $\mathrm{SMA}^{\mathrm{T}}$ was readily filterable through $450 \mathrm{~nm}$ and $220 \mathrm{~nm}$ pore-size filters. A $100 \mathrm{~nm}$ pore-size membrane filtrate was free of viable cells. Strain SMA ${ }^{\mathrm{T}}$ was triply cloned in M1D medium (Whitcomb, 1983) by conventional filtercloning procedures (Tully, 1983a) and designated strain $\mathrm{SMA}^{\mathrm{T}}$. Representative strains of previously recognized groups and subgroups, including the type strains of previously recognized species (Williamson et al., 1998), were cultivated for comparative purposes. All spiroplasmas were grown statically in M1D medium at $30^{\circ} \mathrm{C}$.

\section{Morphological studies}

Dark-field microscopy (magnification $\times 1000$ ) of strain $\mathrm{SMA}^{\mathrm{T}}$ observed during the exponential phase revealed helical cells with four or more turns. Strain SMA ${ }^{\mathrm{T}}$ was highly motile and formed clumps after 3 days in the same culture.

For TEM, $20 \mathrm{ml}$ exponential-phase culture of strain $\mathrm{SMA}^{\mathrm{T}}$ was pelleted and fixed for $2 \mathrm{~h}$ in $3 \%$ glutaraldehyde, postfixed in $1 \%$ osmium tetroxide for $3 \mathrm{~h}$ and then dehydrated in acetone and embedded in Spurr's embedding medium (Williamson, 1983). Sections were stained with $2 \%$ aqueous uranyl acetate and Reynold's lead citrate prior to visualization. As determined by TEM (Fig. 1), cells were filamentous, approximately $150 \mathrm{~nm}$ in diameter and surrounded by a single cytoplasmic membrane.

\section{Serological tests}

Strain $\mathrm{SMA}^{\mathrm{T}}$ was tested serologically against hyperimmune antisera of each of the 40 different spiroplasmas that represent established type strains and subgroup reference strains (Williamson et al., 1998) using the deformation (DF) test (Williamson et al., 1978) and the metabolism inhibition (MI) test (Williamson \& Whitcomb, 1983). Positive reactions for the DF test were confirmed by the presence of grape-like clusters on the spiroplasma, indicative of a reaction between the cell membrane and the antiserum. The presence of normal, helical/spiral-shaped spiroplasmas indicated no reaction to the antiserum (Williamson et al., 1978). Spiroplasma syrphidicola EA-1 ${ }^{\mathrm{T}}$ and Spiroplasma citri $\mathrm{R}_{\mathrm{A}} 2^{\mathrm{T}}$ were also tested against their own antiserum as controls. This procedure was performed twice. Antiserum to strain $\mathrm{SMA}^{\mathrm{T}}$ was produced in rabbits as described previously (Williamson et al., 1978) and used in reciprocal DF tests against strains whose antisera had a positive reaction against strain $\mathrm{SMA}^{\mathrm{T}}$.

DF tests showed that strain $\mathrm{SMA}^{\mathrm{T}}$ exhibited only weak serological reactivity with four representatives from group I: I-3 (Spiroplasma kunkelii E275 ${ }^{\mathrm{T}}$ ) at 1:20, I-4 (Spiroplasma

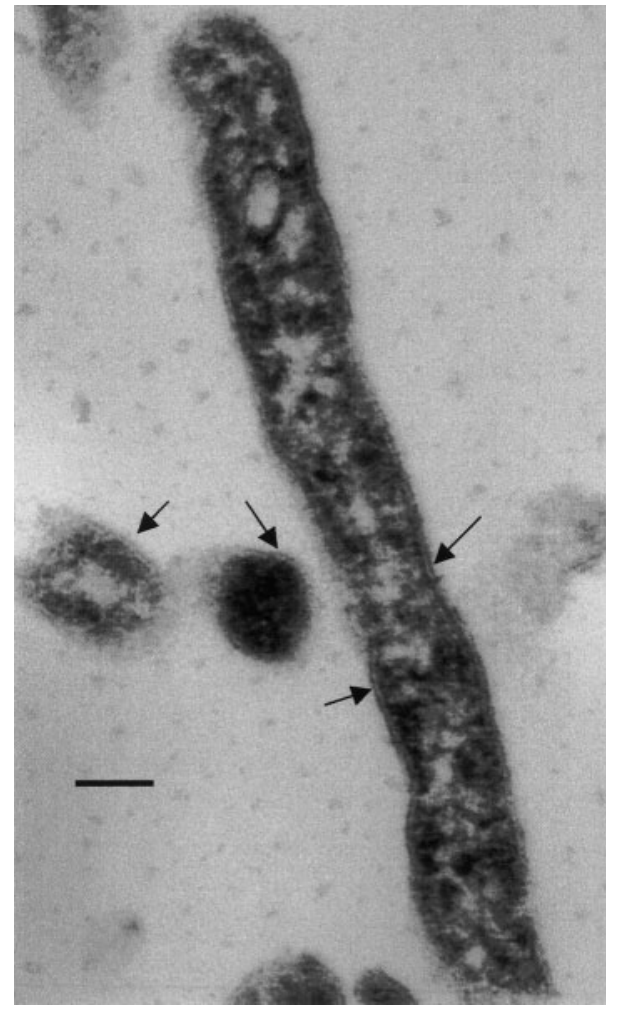

Fig. 1. Transmission electron micrograph of cells of $S$. leucomae strain $\mathrm{SMA}^{\top}$. Arrows indicate the cell membrane. Bar, $0 \cdot 1 \mu \mathrm{m}$.

sp. strain 277F) at $1: 80$, I-5 (Spiroplasma sp. strain LB-12) at $1: 80$ and I-6 (Spiroplasma insolitum $\mathrm{M} 55^{\mathrm{T}}$ ) at $1: 20$. All other reactions were negative. The homologous titre for $S$. citri R8A2 ${ }^{\mathrm{T}}$ was 2560 (Hackett et al., 1996). The homologous titre for strain $\mathrm{SMA}^{\mathrm{T}}$ was 5120 . The MI test results were determined by colour change, or lack thereof, and were performed twice. There were no positive reactions with any of the strains tested in the MI test.

The slight serological cross-reactions with group I spiroplasmas are interesting, as initial observations suggested that infection of satin moth larvae with strain $\mathrm{SMA}^{\mathrm{T}}$ increased insect mortality (J. J. Lipa, unpublished data). Additional tests are planned to determine the degree (if any) of pathogenicity of strain $\mathrm{SMA}^{\mathrm{T}}$ to several lymantriids including the gypsy moth (Lymantria dispar).

\section{Biochemical analysis}

Procedures for determining carbohydrate fermentation, arginine hydrolysis and urea utilization have been described previously (Aluotto et al., 1970). Strain SMA ${ }^{\mathrm{T}}$ was adapted to a minimal medium, SFM supplemented with $1 \%$ bovine serum fraction (Tully, 1983b) and $10 \%$ glucose. After weaning, strain $\mathrm{SMA}^{\mathrm{T}}$ was used to inoculate five tubes for biochemical testing as follows: tube 1 with SFM, tube 2 with SFM and $10 \%$ glucose, tube 3 with SFM and $10 \%$ glucose 
and $21 \%$ arginine, tube 4 with SFM and $21 \%$ arginine and tube 5 with SFM and $1 \%$ urea (Aluotto et al., 1970). Darkfield microscopy, as well as colour change, was used to identify growth of the cultures. A positive test showed growth in ten subsequent dilutions of the original tube and each positive test was repeated three times to ensure reproducibility. After adaptation to SFM supplemented with $10 \%$ glucose, strain $\mathrm{SMA}^{\mathrm{T}}$ was able to grow in media containing glucose, glucose and arginine, and arginine alone, indicating the abilities to ferment glucose and catabolize arginine. No growth was observed in SFM and urea, therefore urea hydrolysis was not observed.

\section{Genome analysis}

Strain $\mathrm{SMA}^{\mathrm{T}}$ was grown in a large culture $(100 \mathrm{ml})$ and DNA was extracted as described previously (Gasparich et al., 1993). The DNA was diluted in $1 \times$ SSC buffer for a final sodium concentration of $0 \cdot 195 \mathrm{M}$. This sample was analysed (with a $1 \times$ SSC buffer blank) in a Cary Varian thermal spectrophotometer equipped with software to determine the melting temperature and the $\mathrm{G}+\mathrm{C}$ content was determined (Carle et al., 1983). This process was repeated several times and Escherichia coli DNA in $1 \times$ SSC buffer was used as a control. The $\mathrm{G}+\mathrm{C}$ base content of strain $\mathrm{SMA}^{\mathrm{T}}$ genomic DNA was measured as $21 \cdot 56,25 \cdot 12$ and $25 \cdot 29 \mathrm{~mol} \%$ (mean $24 \pm 1 \mathrm{~mol} \%$ ).

\section{Phylogenetic analysis}

ATCC accession numbers and GenBank accession numbers for $16 \mathrm{~S}$ rRNA gene sequences used in this study are indicated in Fig. 2(a). Sequences were aligned using CLUSTAL W (Thompson et al., 1994) and then aligned manually in MACCLADE (Maddison \& Maddison, 1992). A 1000 replicate bootstrap analysis was performed using a heuristic search and the tree bisection reconnection parsimony algorithm from PAUP (Fig. 2a) and neighbour-joining analysis using the Jukes-Cantor model for substitutions (Fig. 2b) (version 4.0b; Swofford, 1998). In all analyses, strain $\mathrm{SMA}^{\mathrm{T}}$ consistently grouped with the group VIII subgroups.

This is the first taxonomic and diagnostic description of a spiroplasma isolated from a lepidopteran larva. The white satin moth ( $L$. salicis) is recognized as an invasive alien species and a major pest that defoliates mainly poplar trees (Populus spp.) but is spreading damage to other trees like trembling aspen, black cottonwood and sometimes willow (Humphreys, 1996). Isolation and characterization of strain $\mathrm{SMA}^{\mathrm{T}}$ may contribute to attempts to establish biological control of satin moth larvae, which will be useful in efforts to curb deforestation.

As all the tests needed for the characterization of a novel spiroplasma species, as required by the International Committee on Systematics of Prokaryotes Subcommittee on the Taxonomy of Mollicutes, have been fulfilled, we propose a novel species Spiroplasma leucomae sp. nov.

\section{Description of Spiroplasma leucomae sp. nov.}

Spiroplasma leucomae [leu.co'mae. N.L. gen. fem. n. leucomae of Leucoma, systematic genus name of the white (a)

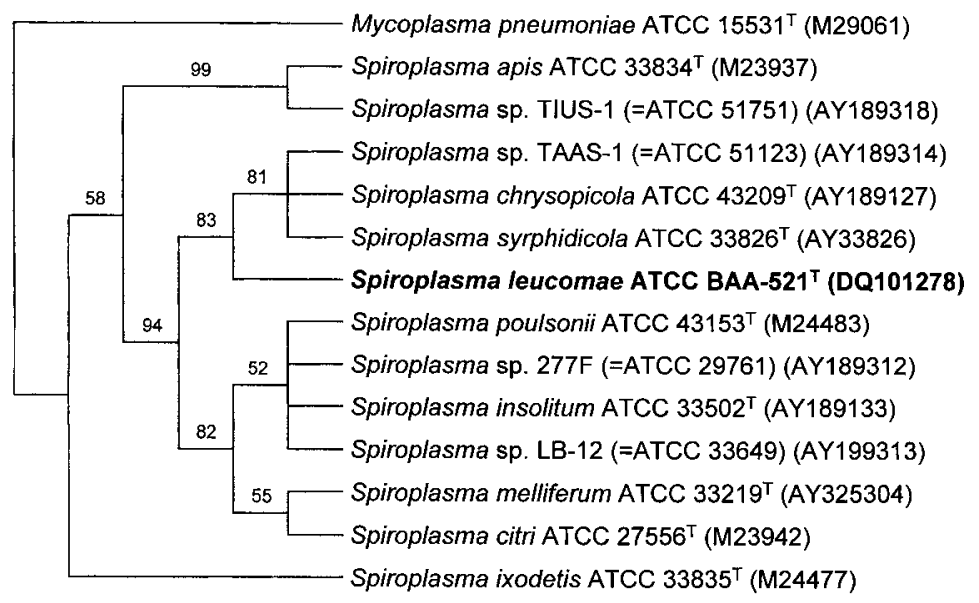

(b)

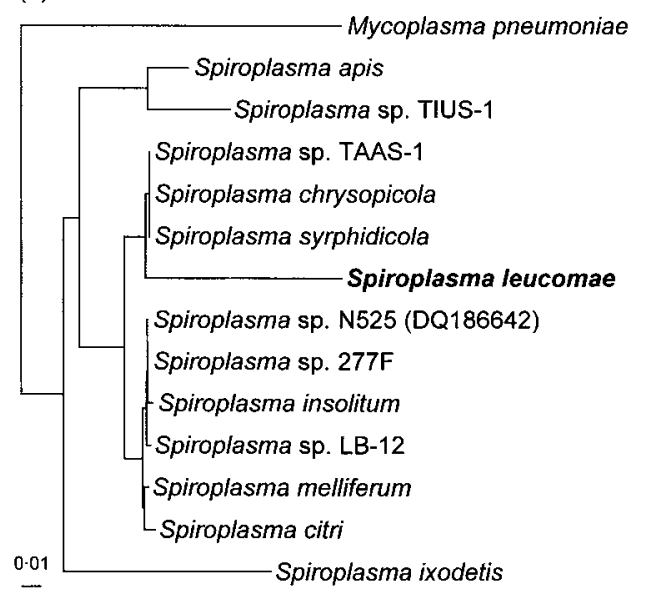

Fig. 2. Phylogenetic trees showing the position of $S$. leucomae strain $S M A^{\top}$ among representatives of the genera Spiroplasma and Mycoplasma. The 16S rRNA gene sequence of $S$. leucomae strain SMA $^{\top}$ was included in a dataset described by Gasparich et al. (2004). Mycoplasma pneumoniae ATCC $15531^{\top}$ was used as an outgroup strain. (a) The tree shows a bootstrap parsimony analysis of the dataset, which was resampled 1000 times. Bootstrap percentage values are given at nodes. ATCC accession numbers are shown next to the organism names and GenBank accession numbers for the 16S rRNA gene sequences used are given in parentheses. (b) Tree constructed by neighbour-joining analysis with the JukesCantor substitution model. Bar, $0 \cdot 01$ substitutions per site. Strain and sequence details are shown in (a) with the exception of strain N525 [not included in (a)]. 
satin moth (Lepidoptera: Lymantriidae), the source of the type strain].

Cells are filamentous, helical and motile, and are approximately $150 \mathrm{~nm}$ in diameter. They pass freely through filters with 450 and $220 \mathrm{~nm}$ pores, but do not pass through filters with $100 \mathrm{~nm}$ pores. The cells lack true cell walls. Chemoorganotrophic. Acid is produced from glucose and arginine is catabolized. Does not utilize urea. Serologically distinct from previously established Spiroplasma species, groups and subgroups. The type strain was isolated from a fifth instar white satin moth (Leucoma salicis) larva. Pathogenicity for these moth larvae is not known. The $\mathrm{G}+\mathrm{C}$ content of the DNA is $24 \pm 1 \mathrm{~mol} \%$ as determined by the melting temperature method.

The type strain is strain $\operatorname{SMA}^{\mathrm{T}}\left(=\right.$ ATCC BAA $-521^{\mathrm{T}}=$ NBRC $\left.100392^{\mathrm{T}}\right)$.

\section{Acknowledgements}

This work was supported in part by the NIH Bridges to the Baccalaureate Grant (\# GM 58384-01A2) and from an NSF Research Experiences for Undergraduates Grant (\# DBI0097478).

\section{References}

Aluotto, B. B., Wittler, R. G., Williams, C. O. \& Faber, J. E. (1970). Standardized bacteriologic techniques for characterization of Mycoplasma species. Int J Syst Bacteriol 20, 35-58.

Carle, P., Saillard, C. \& Bové, J. M. (1983). Determination of guanine plus cytosine content of DNA. Methods Mycoplasmol 1, 301-308.

Gasparich, G. E., Hackett, K. J., Clark, E. A., Renaudin, J. \& Whitcomb, R. F. (1993). Occurrence of extrachromosomal deoxyribonucleic acids in spiroplasmas associated with plants, insects, and ticks. Plasmid 29, 81-93.

Gasparich, G. E., Whitcomb, R. F., Dodge, D., French, F. E., Glass, J. \& Williamson, D. L. (2004). The genus Spiroplasma and its nonhelical descendants: phylogenetic classification, correlation with phenotype and roots of the Mycoplasma mycoides clade. Int J Syst Evol Microbiol 54, 893-918.

Hackett, K. J. \& Clark, T. B. (1989). The ecology of spiroplasmas. In The Mycoplasmas, vol. 5, pp. 113-200. Edited by R. F. Whitcomb \& J. G. Tully. New York: Academic Press.

Hackett, K. J., Whitcomb, R. F., Henegar, R. B., Wagner, A. C., Clark, E. A., Tully, J. G., Molina, F., McKay, W. \& Santini, P. (1990). Mollicute diversity in arthropod hosts. Zentralbl Bakteriol Suppl 20, 441-454.

Hackett, K. J., Whitcomb, R. F., Clark, T. B. \& 12 other authors (1996). Spiroplasma leptinotarsae sp. nov., a mollicute uniquely adapted to its host, the Colorado potato beetle, Leptinotarsa decemlineata (Coloeoptera: Chrysomelidae). Int J Syst Bacteriol 46, 906-911.

Humphreys, N. (1996). Satin Moth in British Columbia. Forest pest leaflet 38. Victoria, BC: Natural Resources Canada, Canadian Forest Service, Pacific Forestry Centre.

International Committee on Systematic Bacteriology Subcommittee on the Taxonomy of Mollicutes (1995). Revised minimum standards for description of new species of the class Mollicutes (division Tenericutes). Int J Syst Bacteriol 45, 605-612.

Konai, M., Clark, E. A., Camp, M., Koch, A. L. \& Whitcomb, R. F. (1996a). Temperature ranges, growth optima, and growth rates of Spiroplasma (Spiroplasmataeae, class Mollicutes) species. Curr Microbiol 32, 314-319.

Konai, M., Hackett, K. J., Williamson, D. L., Lipa, J. J., Pollack, J. D., Gasparich, G. E., Clark, E. A., Vacek, D. C. \& Whitcomb, R. F. (1996b). Improved cultivation systems for isolation of the Colorado Potato Beetle Spiroplasma. Appl Environ Microbiol 62, 3453-3458.

Lipa, J. J., Ziemnicka, J., Gazecka, B. \& Korytek, L. (1988). A newly recorded spiroplasma infection in Stilpnotia salicis L. (Lepidoptera, Lymantriidae). Pr Nauk Inst Ochr Rosl 30, 15-18.

Maddison, W. P. \& Maddison, D. R. (1992). MACCLADE: analysis of phylogeny and character evolution, version 3.0. Sunderland, MA: Sinauer Associates.

Rose, D. L., Tully, J. G., Bové, J. M. \& Whitcomb, R. F. (1993). A test for measuring growth responses of mollicutes to serum and polyoxyethylene sorbitan. Int J Syst Bacteriol 43, 527-532.

Smith, P. F., Lecce, J. G. \& Lynn, R. J. (1954). A lipoprotein as a growth factor for certain pleuropneumonia-like organisms. J Bacteriol 68, 627-633.

Swofford, D. L. (1998). PAUP - Phylogenetic Analysis Using Parsimony and other methods, version 4. Sunderland, MA: Sinauer Associates.

Thompson, J. D., Higgins, D. G. \& Gibson, T. J. (1994). CLUSTAL W: improving the sensitivity of progressive multiple sequence alignment through sequence weighting, position-specific gap penalties and weight matrix choice. Nucleic Acids Res 22, 4673-4680.

Tully, J. G. (1983a). Cloning and filtration techniques for mycoplasmas. Methods Mycoplasmol 1, 173-177.

Tully, J. G. (1983b). Tests for digitonin sensitivity and sterol requirement. Methods Mycoplasmol 1, 355-362.

Whitcomb, R. F. (1983). Culture and media for spiroplasmas. Methods Mycoplasmol 1, 147-158.

Williamson, D. L. (1983). Specialized electron microscopic techniques for spiroplasmas in plant and insect tissues. Methods Mycoplasmol 1, 71-76.

Williamson, D. L. \& Whitcomb, R. F. (1983). Special serological tests for spiroplasma identification. Methods Mycoplasmol 2, 249-259.

Williamson, D. L., Whitcomb, R. F. \& Tully, J. G. (1978). The spiroplasma deformation test, a new serological method. Curr Microbiol 1, 203-207.

Williamson, D. L., Whitcomb, R. F., Tully, J. G. \& 10 other authors (1998). Revised group classification of the genus Spiroplasma. Int J Syst Bacteriol 48, 1-12. 